\title{
Reductive Debromination of 1-Methyl-2,4,5-tribromoimidazole Mediated by Dry Tetramethylammonium Fluoride in Aprotic Solvents
}

\author{
Mônica M. Bastos ${ }^{a, b}$, Jussara P. Barbosa ${ }^{a, b}$, Angelo C. Pinto ${ }^{b}$, Warner B. Kover ${ }^{b}$, Yoshio Takeuchi \\ and Núbia Boechat ${ }^{a *}$ \\ ${ }^{a}$ Departamento de Pesquisa e Desenvolvimento Tecnológico, Far-Manguinhos, Fundação Oswaldo Cruz, \\ R. Sizenando Nabuco, 100, Manguinhos, 21041-250, Rio de Janeiro - RJ, Brazil \\ ${ }^{\mathrm{b}}$ Instituto de Química, Universidade Federal do Rio de Janeiro, 21941-970, Rio de Janeiro - RJ, Brazil \\ ${ }^{c}$ Faculty of Pharmaceutical Sciences, Toyama Medicinal and Pharmaceutical University, Sagitani 2630, \\ Toyama 930-0194, Japan
}

\begin{abstract}
Neste trabalho investigou-se a reação entre fluoreto de tetrametilamônio seco (TMAF) e 1metil-2,4,5-tribromoimidazol em diferentes solventes apróticos polares. Nas reações feitas em DMSO, N,N-dimetilacetamida e N-metilpirrolidona, os principais produtos foram provenientes da desbrominação redutiva e não da fluoração, como esperado, mostrando que o TMAF é fortemente básico nestas condições. A reação feita em DMSO deuterado mostrou que o solvente é a principal fonte de próton. A dimetilformamida foi o solvente menos efetivo como doador de prótons, mas forneceu um rendimento significativo do produto fluorado 4,5-dibromo-2-flúor-1-metilimidazol.

The reaction of dry tetramethylammonium fluoride (TMAF) with 1-methyl-2,4,5tribromoimidazole in different polar aprotic solvents was investigated. Products of reductive debromination were obtained rather than fluorine substitution, indicating that TMAF is strongly basic in such conditions. A reaction carried out in $\mathrm{d}^{6}$-DMSO showed that the solvent is the proton source. Dimethylformamide was less effective that DMSO, N,N-dimethylacetamide or Nmethylpirrolidone as a proton donor and we were able to effect significant fluorination in this solvent.
\end{abstract}

Keywords: tribroimidazole, fluoroimidazole, reductive debromination

\section{Introduction}

Imidazole is an important member of the family of 5membered ring heteroaromatics. It is present in a wide variety of naturally occurring compounds, including histidine and histamine, polymers and dyes. In addition, the imidazole moiety is frequently present as an important structural element in pharmacological and chemotherapeutic agents $^{1-2}$.

In recent years the incorporation of fluorine into bioactive compounds has become increasingly used as a means of obtaining improved effectiveness and increased pharmacological activity ${ }^{3}$.

Despite the large occurrence of the imidazole ring in bioactive compounds, no example of ring fluorinated

\footnotetext{
* e-mail: boechat@far.fiocruz.br
}

imidazole was described before $1971^{4 a}$ at which time the development of the photochemical decomposition of diazonium fluoroborates in aqueous fluoroboric acid led to the synthesis of the first ring-fluorinated imidazole. Other compounds were prepared by this procedure. The yields obtained were between $17-48 \%$.

Attempts to obtain C-F bond via halogen exchange (Halex) from 4-bromo-5-nitroimidazole or 4-bromo-5carbethoxyimidazole with metal alkaline fluorides such as potassium fluoride, cesium fluoride and silver fluoride produced tarry polymers with no evidence for halogen exchange $^{4 b}$. The low solubility of the metal alkaline fluoride in aprotic polar organic solvents (e.g. saturation of DMSO with $\mathrm{KF}$ at $25^{\circ} \mathrm{C}$ corresponds to $8 \mathrm{mg}$ of fluoride $/ 100 \mathrm{~g}$ solvent $)^{5}$ and the high temperature required for this reaction $\left(130-210^{\circ} \mathrm{C}\right)$ are probably causes for their limited use. A recent example of direct fluorination of imidazole ${ }^{6}$ with 
KF in good yield by Halex used the highly activated 2bromo-4,5-dicyano-1-methylimidazole as substrate in a nucleophilic aromatic substitution carried out in the presence of 18-crown-6.

We have found that anhydrous tetramethylammonium fluoride (TMAF) is a highly effective reagent for the preparation of a selectively fluorinated aromatic molecules via nucleophilic aromatic substitution ${ }^{7}$. TMAF permits milder reaction conditions and shorter reaction times, being much more soluble and reactive than KF. It can fluorinate aromatic substrates that are unreactive using $\mathrm{KF}$ as the fluoride source. We now have investigated the reaction of TMAF with 1-methyl-2,4,5-tribromoimidazole in various solvents. Results are given below.

\section{Results and Discussion}

1-Methyl-2,4,5-tribromoimidazole (1) was obtained in essentially quantitative yield from the commercially available 2,4,5-tribromoimidazole by methylation with $\mathrm{CH}_{2} \mathrm{~N}_{2}$. Reactions with dried TMAF (2 equiv.) were carried out at $100^{\circ} \mathrm{C}$ and followed by GC and ${ }^{19} \mathrm{~F}$ NMR spectroscopy. The reaction carried out in DMSO during $3 \mathrm{~h}$ produced only $1 \%$ of 1 -methyl-4,5-dibromo-2fluoroimidazole (2), together with $38 \%$ of the starting material 1. Unexpectedly, $43 \%$ of 2,4-dibromo-1methylimidazole (3) and $16 \%$ of 4,5-dibromo-1methylimidazole (4) were obtained. The isomers 3 and 4 were separated by HPLC at normal phase using hexane/ $\mathrm{CHCl}_{3}$ (3:7). In the ${ }^{1} \mathrm{H}$ NMR spectra isomer 3 showed a signal at $\delta 6.93$ typical of a proton at the imidazole 2 position $^{8}$ while isomer 4 gave a signal at $\delta 7.46$, corresponding to the hydrogen at the 4 or 5 position. Irradiation of the methyl absorption at $\delta 3.60$ and 3.63 for 3 and 4, respectively, produced nuclear Overhauser effects (nOe), thus establishing the hydrogen as being at the 5 and 2 positions, and not at the 4 position.

The ${ }^{19} \mathrm{~F}$ NMR spectrum of the reaction mixture showed an absorption at $\delta-107,4$ identical to the expected compound $\mathbf{2}$, previously obtained by fluorodenitration ${ }^{9}$.
Such dehalogenations are not without precedent in the literature but they were obtained previously in the presence of a base and a proton-source such as an alcohol ${ }^{10}$ or water ${ }^{11,12}$. It follows from the reductive dehalogenation products we obtained that fluoride acted more as base than as nucleophile in this reaction. The basicity of the fluoride ion is known to be highly dependent on the counter-cation, the level of hydration and the reaction solvent ${ }^{5}$. These contributing factors help to explain the inconsistencies of reported basicities of fluoride. Tetraalkylammonium fluorides are soluble in polar aprotic solvents although their hygroscopicity is such that on dissolution the fluoride will almost certainly be accompanied by varying amounts of water or some other protic material. If only traces of protic material are present, then the basicity of the solution is such that the fluoride may be capable of abstracting a proton from a weakly acid solvent such as $\mathrm{DMSO}^{13}$ or acetonitrile $^{14}$. Recently, Clark ${ }^{15}$ showed that the high basicity of TMAF causes H-D exchange in 1,3dinitrobenzene, as well as deprotonation of N,Ndimethylacetamide (DMAc).

In order to determine whether the hydrogen atom incorporated into the products come from the solvent, we carried out a similar experiment in $\mathrm{d}^{6}$-DMSO. After $3 \mathrm{~h}$ at $100^{\circ} \mathrm{C}$ only $9 \%$ of starting material remained. The reaction mixture was separated by normal phase HPLC using hexane $/ \mathrm{CHCl}_{3}$ (3:7) to give 5-deutero-2,4-dibromo-1methylimidazole (5) and 2-deutero-4,5-dibromo-1methylimidazole (6) in a 8:2 ratio, respectively.<smiles>[2H]c1c(Br)nc(Br)n1C</smiles>

5<smiles>[2H]c1nc(Br)c(Br)n1C</smiles>

6
Spectral data were compared to the data of the corresponding non-deuterated compounds: $\mathbf{3}$ with $\mathbf{5}$ and $\mathbf{4}$ with 6. The mass spectra of compounds 5 and $\mathbf{6}$ showed peaks corresponding to the peaks of compounds $\mathbf{3}$ and $\mathbf{4}$,<smiles>Cn1c(Br)nc(Br)c1Br</smiles>

1<smiles>Cn1c(F)nc(Br)c1Br</smiles>

2<smiles>Cc1nc(Br)cn1C</smiles>

3<smiles>Cn1c(Br)nc(Br)c1Br</smiles>

4

Figure 1. Reaction of 1-methyl-tribromoimidazole (1) with TMAF in DMSO 
respectively, with one unit of mass added. The ${ }^{13} \mathrm{C}$ NMR analyses of $\mathbf{5}$ and $\mathbf{6}$ showed C-D peaks at $\delta 123.0$ and 137.5, respectively, with low intensity signals that correspond to $\mathrm{C}-\mathrm{H}$ in $\mathbf{3}\left(\delta\right.$ 123.0) and $\mathbf{4}\left(\delta\right.$ 137.4). The ${ }^{1} \mathrm{H}$ NMR analyses showed an isotopic ratio $\mathrm{H} / \mathrm{D}$ of $1: 3.8$ for $\mathbf{3}$ and $\mathbf{5}$ and 1:3.3 for $\mathbf{4}$ and $\mathbf{6}$.

The following mechanism is compatible with these observations $^{10 a}$ :

$$
\begin{aligned}
\mathrm{B}^{-}+\mathrm{CH}_{3} \mathrm{SOCH}_{3} & \rightarrow \mathrm{CH}_{2} \mathrm{SOCH}_{3}+\mathrm{HB} \\
\mathrm{CH}_{2} \mathrm{SOCH}_{3}+\mathrm{ArBr} & \rightarrow \mathrm{Ar}^{-}+\mathrm{BrCH}_{2} \mathrm{SOCH}_{3} \\
\mathrm{HB}+\mathrm{Ar}^{-} & \rightarrow \mathrm{ArH}+\mathrm{B}^{-}
\end{aligned}
$$

In order to study the role of the tetramethylammonium cation in the process of debromination, a reaction of $\mathbf{1}$ was carried out using KF as the fluoride source with tetramethylammonim bromide as phase transfer catalyst and DMSO as solvent. After $3 \mathrm{~h}$ only traces of the fluorinated product 2 was observed. However, reductive debromination products were not formed suggesting that the KF intimate ion pairs lack sufficient basicity to deprotonate DMSO and that the use of TMAF is critical to the observed reaction.

Aprotic polar solvents are known as "semiprotic" in the sense that they can supply protons to strong bases and form reactive carbanions. Bunnett ${ }^{10 a}$ measured the extent of debromination of 1-bromo-2,6-dichlorobenzene in several aprotic solvents and found the following order of proton donor ability: DMSO > N-methylpirrolidone (NMP) > N,N-dimethylacetamide (DMAc) $>>$ dimethylformamide (DMF).

Based on these data, reactions were carried out in DMF, NMP and DMAc, while keeping other reaction parameters constant, in an attempt to reduce hydrodebromination and improve the yield of fluorinated product. Results are presented in Table 1. Data were obtained by GCMS analysis of the reaction mixtures, since all compounds have been previously isolated and characterized.

The reaction in DMAc gave results similar to the reaction in DMSO although the yield of compound $\mathbf{3}$ was increased. NMP also resulted in reductive debromination but no significant regioselectivity between those products was shown. DMF proved to be a poor proton source compared to the others. A significant increase in yield (19$24 \%$ ) of the fluorinated product 2 was observed while 65$81 \%$ of unreacted starting material was still present. Allowing the reaction to proceed for a longer time (e.g. $24 \mathrm{~h}$ ) did not improve the yield of fluorinated product. The selectivity of fluorination at position 2 could be anticipated because of the high electrophilicity of C-2 that facilitates nucleophilic aromatic substitution of fluoride ion.
This selectivity ratio of reductive debromination products is consistent with two previous observations. First, it has been described that halogens located ortho to one another are preferentially removed ${ }^{16}$. Second, basecatalyzed exchange on $\mathrm{N}$-alkylimidazoles occurs by a carbanion pathway, in which a proton is abstracted from the neutral imidazole species only at C-5. The resistance to carbanion formation at $\mathrm{C}-4$ was attributed to the adjacent lone pair (ALP) effect ${ }^{17}$.

In conclusion, we have shown that dry TMAF in polar aprotic solvent (DMSO, DMAc and NMP) at $100^{\circ} \mathrm{C}$ converts compound $\mathbf{1}$ to a fluorinated product in only trace amounts. The main products resulted from reductive debromination and the regioselectivity of reduction was $5 \mathrm{H}>2 \mathrm{H}$. The hydrogen that is incorporated into the product comes mainly from the solvent but the high hygroscopicity of TMAF also provides water as a proton source. As described by Bunnett, DMF is a less effective proton donor than the other aprotic solvents examined but significant fluorination (19-24\%) was obtained. Reductive bromination did not occur when KF was a fluoride source, possibly because of strong ion pairing.

Table 1. Reaction of 1 with TMAF (1: 2equiv. ), $100^{\circ} \mathrm{C}, 3 \mathrm{~h}$.

\begin{tabular}{lrrrr}
\hline & \multicolumn{4}{c}{ Compound $(\%)^{*}$} \\
\cline { 2 - 5 } Solvents & $\mathbf{1}$ & $\mathbf{2}$ & $\mathbf{3}$ & $\mathbf{4}$ \\
\hline DMSO & 38 & $\mathrm{t}$ & 43 & 16 \\
DMAc & 18 & $\mathrm{t}$ & 62 & 19 \\
NMP & 22 & 4 & 20 & 20 \\
DMF & 65 & 24 & 7 & 3 \\
\hline
\end{tabular}

*GC; $\mathrm{t}=$ trace

\section{Experimental}

Melting points were recorded on a Koffler apparatus and are uncorrected. ${ }^{1} \mathrm{H}$ NMR, ${ }^{13} \mathrm{C}$ NMR and ${ }^{19} \mathrm{~F}$ NMR were recorded using a Bruker $\mathrm{HC} 200$ spectrometer operating at 200, 50 and $188 \mathrm{MHz}$, respectively. Chemical shifts values in ppm $(\delta)$ are reported with TMS as internal reference for ${ }^{1} \mathrm{H}$, relative to appropriate solvent for ${ }^{13} \mathrm{C}$ and $\mathrm{CFCl}_{3}$ for ${ }^{19} \mathrm{~F}$. The ${ }^{13} \mathrm{C}$ NMR spectra were obtained using broad band proton decoupling. Mass spectra coupled with gas cromatography $(70 \mathrm{eV})$ were recorded on a HP6890. Gas cromatography analyses were recorded on a Shimadzu GC14B. HPLC analysis were recorded on a Shimadzu apparatus having a Shim-pack CLC-SIL (M) column for normal phase. HRMS $(70 \mathrm{eV})$ spectra were obtained on a VG autospec HP instrument. Separations by HPLC were carried out on a Shimadzu apparatus using a Shim-Pack Prep-SIL for normal phase. 
General procedure

Commercially available tetramethylammonium fluoride tetrahydrate was dried by long-term heating under vacuum (7 days). Reactions were carried in a conventional round bottom flask fitted with a reflux condenser under magnetic stirring and nitrogen atmosphere using 2 mol equiv. of dried TMAF in a polar aprotic solvent. The mixture was stired at $100^{\circ} \mathrm{C}$ for $3 \mathrm{~h}$, then quenched with diethyl ether and washed with water ( 3 times). Products from the reactions with DMSO and $\mathrm{d}^{6}$-DMSO were separated by HPLC normal phase using hexane/ $\mathrm{CHCl}_{3}$ (3:7). All products of reactions with DMAc, DMF and NMP were characterized by GCMS analysis and ${ }^{19} \mathrm{~F}$ NMR spectroscopy.

4,5-dibromo-2-fluoro-1-methylimidazole (2)

${ }^{19} \mathrm{~F} \mathrm{NMR}\left(\mathrm{CDCl}_{3}, 188 \mathrm{MHz}\right) \delta-107.4(\mathrm{~s}, 1 \mathrm{~F}) ; \mathrm{m} / \mathrm{z} 260$ $(\mathrm{M}+4,48 \%), 258(\mathrm{M}+2,100), 256\left(\mathrm{M}^{+}, 52\right), 245(9), 215$ (5), 196 (1), 177 (5), 136 (20), 120 (10), 105 (5), 98 (18), $79(8), 52(8)$.

\section{2,4-dibromo-1-methylimidazole (3)}

Eluent: hexane/chloroform (3:7); (0.100 g, 33\%); white solid, mp 80-81 ${ }^{\circ} \mathrm{C}$; IR $v_{\max } / \mathrm{cm}^{-1} 3108,2942$ (KBr); ${ }^{1} \mathrm{H}$ NMR $\left(\mathrm{CDCl}_{3}, 200 \mathrm{MHz}\right) \delta 3.60(\mathrm{~s}, 3 \mathrm{H}), 6.93(\mathrm{~s}, 1 \mathrm{H}) ;{ }^{13} \mathrm{C} \mathrm{NMR}$ $\left(\mathrm{CDCl}_{3}, 50 \mathrm{MHz}\right) \delta 35.5,115.2,119.5,123.0 ; \mathrm{m} / \mathrm{z} 242$ $(\mathrm{M}+4,50 \%), 240(\mathrm{M}+2,100), 238\left(\mathrm{M}^{+}, 52\right), 223(2), 159$ (4), 144 (2), 120 (22), 117 (4), 80 (17), 65 (6).

\section{4,5-dibromo-1-methylimidazole (4)}

Eluent: hexane/chloroform (3:7); (0.021 g, 7\%); white solid, mp 79-81 ${ }^{\circ} \mathrm{C}\left(\right.$ lit $\left.^{8} .80{ }^{\circ} \mathrm{C}\right)$; IR $v_{\max } / \mathrm{cm}^{-1} 3108,2946$, 2872 (KBr); ${ }^{1} \mathrm{H} \mathrm{NMR}\left(\mathrm{CDCl}_{3}, 200 \mathrm{MHz}, \mathrm{TMS}\right) \delta 3.63$ $(\mathrm{s}, 3 \mathrm{H}), 7.46(\mathrm{~s}, 1 \mathrm{H}){ }^{8} ;{ }^{13} \mathrm{C} \mathrm{NMR}\left(\mathrm{CDCl}_{3}, 50 \mathrm{MHz}\right) \delta 33.9$, 104.4, 116.9, 137.4; m/z $242(\mathrm{M}+4,48 \%), 240(\mathrm{M}+2,100)$, $238\left(\mathrm{M}^{+}, 50\right), 201$ (4), 199 (9), 197 (4), 161 (47), 159 (50), 146 (4), 144 (4), 134 (40), 132 (47), 122 (15), 120 (22), 119 (10), 117 (9), 107 (12), 105 (15), 65 (3).

\section{5-deutero-2,4-dibromo-1-methylimidazole (5)}

Eluent: hexane/chloroform (3:7); (0.147 g, 49\%); white solid, mp 65-67 ${ }^{\circ} \mathrm{C}$; IR $v_{\max } / \mathrm{cm}^{-1} 3112(\mathrm{KBr}) ;{ }^{1} \mathrm{H}$ NMR $\left(\mathrm{CDCl}_{3}, 200 \mathrm{MHz}, \mathrm{TMS}\right) \delta 3.60(\mathrm{~s}, 3 \mathrm{H}) ;{ }^{13} \mathrm{C} \mathrm{NMR}\left(\mathrm{CDCl}_{3}\right.$, $50 \mathrm{MHz}) \delta 35.4,114.9,119.4,123.0 ; \mathrm{m} / \mathrm{z} 243(\mathrm{M}+4,40 \%)$, $241(\mathrm{M}+2,100), 239\left(\mathrm{M}^{+}, 42\right), 200$ (8), 198 (14), 196 (5), 120 (20), 81 (46), 66 (8); HRMS (M+). Found: 240.86223. Calc. for $\mathrm{C}_{4} \mathrm{H}_{3} \mathrm{DBr}_{2} \mathrm{~N}_{2}: 240.86222$. 2-deutero-4,5-dibromo-1-methylimidazole (6)

Eluent: hexane/chloroform (3:7); (0.033 g, 11\%); white solid, mp 71-73 ${ }^{\circ} \mathrm{C}$; IR $v_{\max } / \mathrm{cm}^{-1}: 2923(\mathrm{KBr}) ;{ }^{1} \mathrm{H}$ NMR $\left(\mathrm{CDCl}_{3}, 200 \mathrm{MHz}, \mathrm{TMS}\right) \delta 3.63(\mathrm{~s}, 3 \mathrm{H}) ;{ }^{13} \mathrm{C} \mathrm{NMR}\left(\mathrm{CDCl}_{3}\right.$, $50 \mathrm{MHz}) \delta 33.9,104.4,117.0,137.5 ; \mathrm{m} / \mathrm{z} 243(\mathrm{M}+4,38 \%)$, $241(\mathrm{M}+2,78), 239\left(\mathrm{M}^{+}, 28\right), 226(8), 200$ (14), 198 (18), 196 (12), 162 (30), 160 (32), 150 (50), 132 (90), 119 (26), 117 (26), 52(100); HRMS (M+). Found: 240.86249. Calc. for $\mathrm{C}_{4} \mathrm{H}_{3} \mathrm{DBr}_{2} \mathrm{~N}_{2}: 240.86222$.

\section{Acknowledgements}

This work was supported by Far-Manguinhos/Fundação Oswaldo Cruz. ACP and WBK thank the CNPq for senior research fellowships.

\section{References}

1. Grimmett, M. R. Adv. Heterocycl. Chem. 1970, 12, 103.

2. Breccia, A.; Cavalleri, B.; Adams, G. E. Nitroimidazoles Chemistry, Pharmacology and Clinical Application, Plenum Press. New York, 1982.

3. Welch J.T. ; Eswarakrihnan, S. Fluorine in Bioorganic Chemistry, John Wiley \& Sons, New York, 1991.

4. (a) Kirk, K. L.; Cohen, L. A. J. Am Chem. Soc. 1971, 93, 3060; (b) Kirk K. L.; Cohen, L. A. J. Am. Chem. Soc. 1973, 95, 4619; (c) Takahashi, K.; Kirk, K. L.; Cohen, L. A. J. Org. Chem. 1984, 49, 1951 and references therein; (d) Fabra, F.; Galvez, C.; Gonzales, A.; Viladoms, P.; Vilarrasa, J. Heterocycl. Chem. 1978, 15, 1227.

5. Clark, J. H. Chem. Rev. 1980, 80, 429

6. Subrayan, R. P.; Rasmussen, P.G. Tetrahedron 1995, $51,6167$.

7. (a) Boechat, N.; Clark, J. H. J. Chem. Soc., Chem. Commun. 1993, 921; (b) Clark, J. H.; Wails, D.; Jones, C. W.; Smith, H., Boechat, N.; Mayer, L. U.; Mendonça J. S. J. Chem. Research (S) 1994, 478.

8. Calo, V.; Ciminale, F.; Lopez, L.; Naso, F.; Todesco, P. E. J. Chem. Soc., Perkin Trans 1 1972, 2567.

9. Boechat, N; Barbosa, J. P.; Macedo, M. G.; Pinto, A. C. Abstract of the $12^{\text {th }}$ European Symposium on Fluorine Chemistry, Berlin, Germany, 1998, P-1.

10. (a) Bunnett, J. F.; Victor, R. R. J. Am. Chem. Soc. 1968, 90, 810; (b)Iddon, B.; Khan, N.; Lim, B. L. J. Chem. Soc., Perkin Trans 1 1987, 1457.

11. Iddon, B.; Khan, N. Tetrahedron Lett. 1986, 27, 1635.

12. Apen, P. G.; Rasmussen, P. G. J. Heterocycl. Chem. 1992, 29, 1091

13. Reichardt, C. Solvents and Solvent Effects in Organic Chemistry, VCH, $2^{\text {nd }}$ Ed., p.232, New York, 1990. 
14. Christe, K. O.; Wilson, W. W.; Wilson, R. D.; Bau, R.; Feng, J. J. Am. Chem. Soc. 1990, 112, 7619.

15. Adams, D. J.; Clark, J. H.; Nightingale, D. J. Tetrahedron 1999, 55, 7725

16. Bunnett, J. F. Acc. Chem. Res. 1972, 5, 139.
17. (a) Takeuchi, Y.; Yeh, H. J. C.; Kirk, K. L.; Cohen, L. A. J. Org. Chem. 1978, 43, 3565; (b) Takeuchi, Y.; Kirk, K. L.; Cohen, L. A. J. Org. Chem. 1978, 43, 3570 .

Received: November 14, 2000 Published on the web: May 16, 2001 